Materiales de Construcción

Vol. 70, Issue 338, April-June 2020, e214

ISSN-L: 0465-2746

https://doi.org/10.3989/mc.2020.06519

\title{
Characteristics and properties of Bitlis ignimbrites and their environmental implications
}

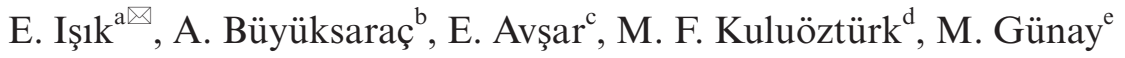 \\ a. Bitlis Eren University, Civil Eng. Dept., Bitlis, Turkey \\ b. Canakkale Onsekizmart University, Can Vocational School Canakkale, Turkey \\ c. Bitlis Eren University, Environmental Eng. Dept., Bitlis, Turkey \\ d. Bitlis Eren University, Electric and Electronic Eng. Dept., Bitlis,Turkey \\ e. Bitlis Eren University, Pure and Applied Science Institute, Civil Eng. Dept., Bitlis, Turkey \\ $\triangle$ : eisik@beu.edu.tr
}

Received 2 May 2019

Accepted 24 September 2019

Available on line 6 April 2020

\begin{abstract}
Bitlis rock is used as a construction material and comes from the lava emitted by volcanoes and their subsequent transformation into ignimbrites. This type of rocks has been characterized physically, chemically, toxicologically and radioactively using different procedures including determination of the coefficient of thermal conductivity, gamma spectrometry, ultrasonic speed test, ICP masses and metal extraction. The results indicate that Bitlis rocks have an ACI greater than 1, although their content of radon is lower than other rocks of volcanic origin. Leaching of metals from these rocks indicates that $\mathrm{Pb}$ and $\mathrm{Cd}$ can provide an infiltration level in the field higher than the level permitted by TCLP and they have undesired toxicological risks. The percentages of extraction of other metals also point to this infiltration problem. Despite this, the material offers good qualities for usage as a building material such as its thermal coefficients.
\end{abstract}

KEYWORDS: Bitlis; Thermal Analysis; Physical properties; Mechanical properties; Ignimbrite; Heavy metals.

Citation/Citar como: Ișı1k, E.; Büyüksaraç, A.; Avşar, E.; Kuluöztürk, M.F.; Günay, M. (2020) Characteristics and properties of Bitlis ignimbrites and their environmental implications. Mater. Construcc. 70 [338], e214 https://doi. org/10.3989/mc.2020.06519

RESUMEN: Características y propiedades de los ignimbritos de Bitlis y sus implicaciones ambientales. La roca Bitlis se utiliza como material de construcción y proviene de la lava emitida por los volcanes y su posterior transformación en ignimbritas. Este tipo de rocas se ha caracterizado física, química, toxicológica y radioactivamente utilizando diferentes procedimientos, incluida la determinación del coeficiente de conductividad térmica, espectrometría gamma, prueba de velocidad ultrasónica, ICP masas y extracción de metales. Los resultados indican que las rocas Bitlis tienen un ACI mayor que 1, aunque su contenido de radón es más bajo que el de otras rocas de origen volcánico. La lixiviación de metales de estas rocas indica que el $\mathrm{Pb}$ y el Cd pueden proporcionar un nivel de infiltración en el campo más alto que el nivel permitido por TCLP y tener riesgos toxicológicos no deseados. Los porcentajes de extracción de otros metales también apuntan a este problema de infiltración. A pesar de esto, el material ofrece buenas cualidades para su uso como material de construcción, como pueden ser sus coeficientes térmicos.

PALABRAS CLAVE: Bitlis; Análisis térmico; Propiedades físicas; Propiedades mecánicas; Ignimbrita; Metales pesados.

ORCID ID: E. Işı1k (https://orcid.org/0000-0001-8057-065X); A. Büyüksaraç (https://orcid.org/0000-0002-4279-4158); E. Avşar (https://orcid.org/0000-0001-6249-4753); M.F. Kuluöztürk (https://orcid.org/0000-0001-8581-2179); M. Günay (https://orcid.org/0000-0003-3242-4900)

Copyright: (C) 2020 CSIC. This is an open-access article distributed under the terms of the Creative Commons Attribution 4.0 International (CC BY 4.0) License. 


\section{INTRODUCTION}

Granular volcanic rocks are formed due to volcanic eruptions with high gas pressure. One of these products is pyroclastic rocks. Pyroclastics are volcanic materials coming from a volcanic chimney to the surface through volcanic mechanisms and wind by means of a sedimentation to bring to gather with the temperature of more than $500-600^{\circ} \mathrm{C}$ in boiling or fusion form of glass or glassy parts as a result of the rotation of the product with minerals (zeolite) that are from the rocks formed. Ignimbrite is a pyroclastic flow unit that contains large amounts of pumice, volcanic glass and a small amount of lithic particles, with a flowing in high temperature, laminar flow system and gravity control (1-10). Locally, Bitlis stone is found in the volcanic tuff group. Bitlis ignimbrite is found in different thicknesses by spreading the lava from the Nemrut volcano to the environment. Bitlis ignimbrite is one of the most widely used natural building stones in the city of Bitlis due to its low unit weight and easy formability. Bitlis stone used in historical artefacts in the province of Bitlis may be in different colours. Bitlis stone was used widely in historical buildings such as Bitlis Castle, baths, tombs, mosques, minarets and traditional Bitlis houses. Today, it areas of usage are limited with the development of concrete technology. Nowadays, it is used especially in renewed buildings and rural areas. Bitlis stone obtained from quarries is used in the production area or at the construction site by cutting.

Bitlis ignimbrite is composed of shard, pumice and pumice parts, crystal and crystal pieces and lytic components in terms of its petrographic components. The mineralogical composition of the sanidine + plagioclase + anorthoclase + pyroxene (augite) + opaque minerals are seen. On some levels of Bitlis ignimbrite, micro-scale cracks resulting from sudden cooling of the volcanic glass are seen (11). Microscopic images of the mineralogical components of the Bitlis ignimbrite are shown in Figure 1. Bitlis stone may be used as a lightweight concrete or as a stone wall for insulation purposes because of its independent pores in the macro and micro dimensions.

In the context of this multidisciplinary study, the physical and chemical properties of ignimbrite rocks as a building material were determined and compared to other rocks of volcano origin. The rocks' toxicological and radioactive characteristics were also investigated in terms of environmental and public health concerns.

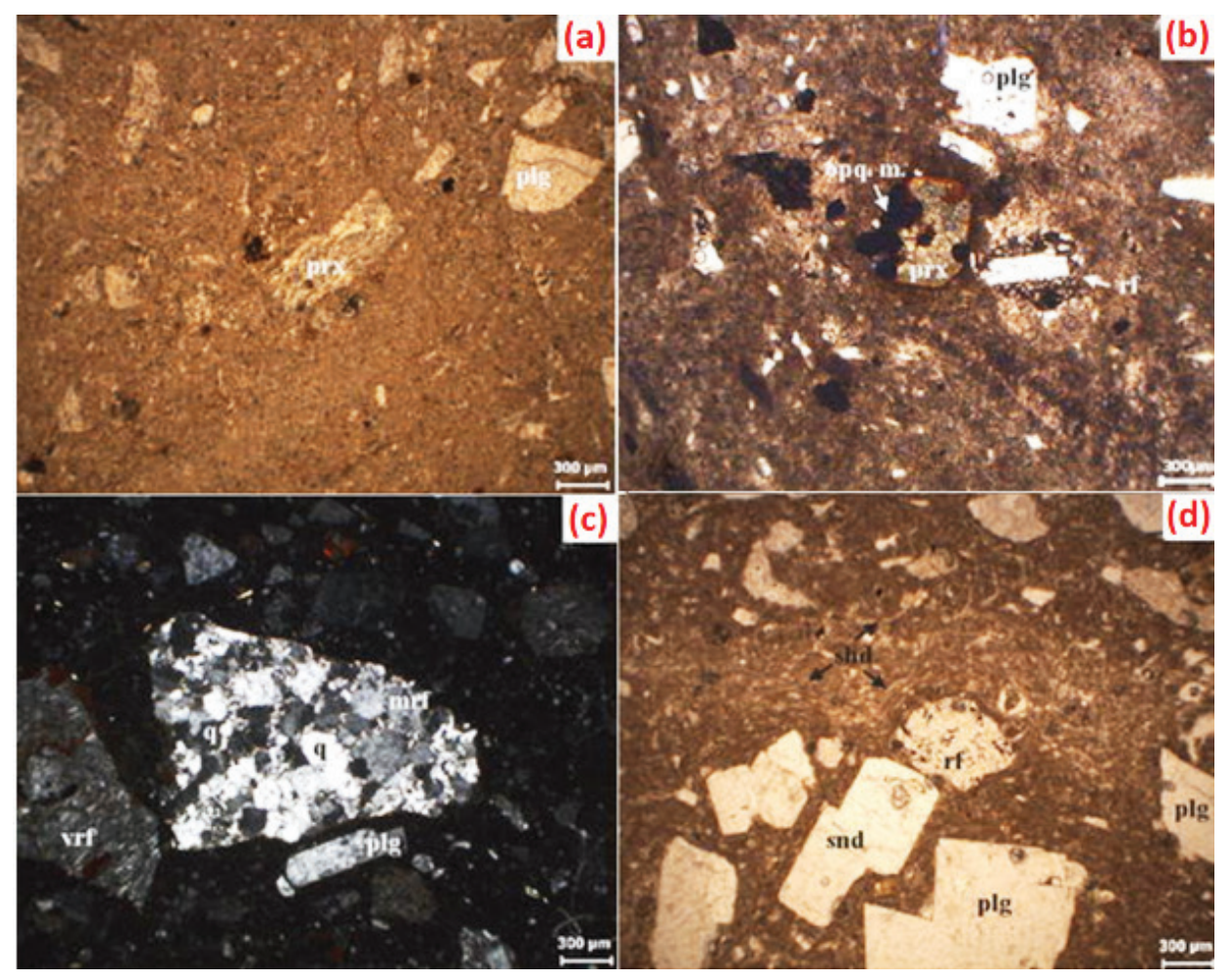

FIgURE 1. Microphotographs of mineral components of Bitlis ignimbrite, a, b) slight pleochroism and Fe-Ti oxide inclusions in pyroxene c) rock fragments are angular in shape d) fibrous shape shard components (snd: sanidine, plg: plagioclase, prx: pyroxene, opq. m: opaque mineral, rf: rock fragment, vrf: volcanic rock fragment, mrf: metamorphic rock fragment, q: quartz, shd: shard) $(7,11)$. 
Therefore, Bitlis stone samples were obtained from a quarry and then brought to the dimensions to be used in the study by using stone cutting machinery. Dry unit volume weight, wet unit weight, water absorption percentage, thermal conductivity coefficient, specific heat, pressure and tensile strength were determined by standard tests. In addition to physical and chemical properties of building materials, determination of radiological parameters such as mass attenuation coefficient, gamma and radon gas emission is important for human health (12-14). In this study, the mass attenuation coefficient, gamma radioisotope concentration and radon gas emission of Bitlis stone were determined by using nuclear methods. Likewise, environmental toxicity in terms of heavy metal leaching characteristics was tested according to TCLP method described by the US Environmental Protection Agency (USEPA).

This study is important in terms of being comprehensive on the topic of ignimbrites that form as a result of volcanic activity. In this study, the environmental toxicity and radiological characteristics of Bitlis ignimbrite were investigated and evaluated together with the physical and mechanical properties of the ignimbrite.

There has been no study on Bitlis stone in this context. There are studies on ignimbrite (Ahlat stone) which is a product of the Nemrut and Suphan Volcanoes in general. However, the scope of these studies is not as broad as the scope of our study.

\section{MATERIAL AND METHODS}

Bitlis stone samples obtained from quarries were brought to $15 \mathrm{~cm} \times 15 \mathrm{~cm} \times 15 \mathrm{~cm}$ dimensions by using a stone cutting machine determine their mechanical and physical properties. The images of these samples are given in Figure 2. Some samples were also milled with Bitlis stone using a grinder.
The experiments were carried out at four different laboratories (Bitlis Provincial Environmental Directorate Building Laboratory, Dicle University Material Laboratory, Agri Ibrahim Cecen University Center Research and Application Laboratory and Firat University Laboratory). The mean values obtained from the different samples were analyzed and ignimbrite (Bitlis stone) properties were determined.

The number of samples taken for each experiment is shown in the results and discussion section. Tests were carried out in accordance with the procedures laid out in the Suggested Methods and Turkish Standards (15).

Bitlis stone samples were prepared as two types for radiological analysis. Firstly, the samples were cut in the shape of rectangular prisms with approximately $5 \mathrm{~cm} \times 5 \mathrm{~cm} \times 1 \mathrm{~cm}$ dimensions for determination of their linear attenuation coefficients (16). Then the samples were crushed and sieved by a 40 mesh sieve. The sieved samples were placed in a marinelli beaker in $1 \mathrm{~L}$ of volume and a cylindrical container with a CR-39 passive radon detector, tightly closed and stored for about 40 days to reach final equilibrium between 222Rn and its short-lived daughters for gamma radioisotope and radon analysis $(17,18)$.

The experimental study for environmental properties was carried out according to the EPA Test Method 1311 TCLP procedure. TCLP (Toxicity characteristic infiltration procedure) was developed to determine the mobility of organic and inorganic analyses present in solid, liquid or multi-phase wastes (19). Rainwater and other liquids can interact with wastes while they are drained from storage areas. In this process, they can solve the pollutants in the waste content. This poses a health and environmental risk. TCLP is a preliminary step in identification of non-volatile pollutants in solids and waste (20). Thus, the TCLP method is used to
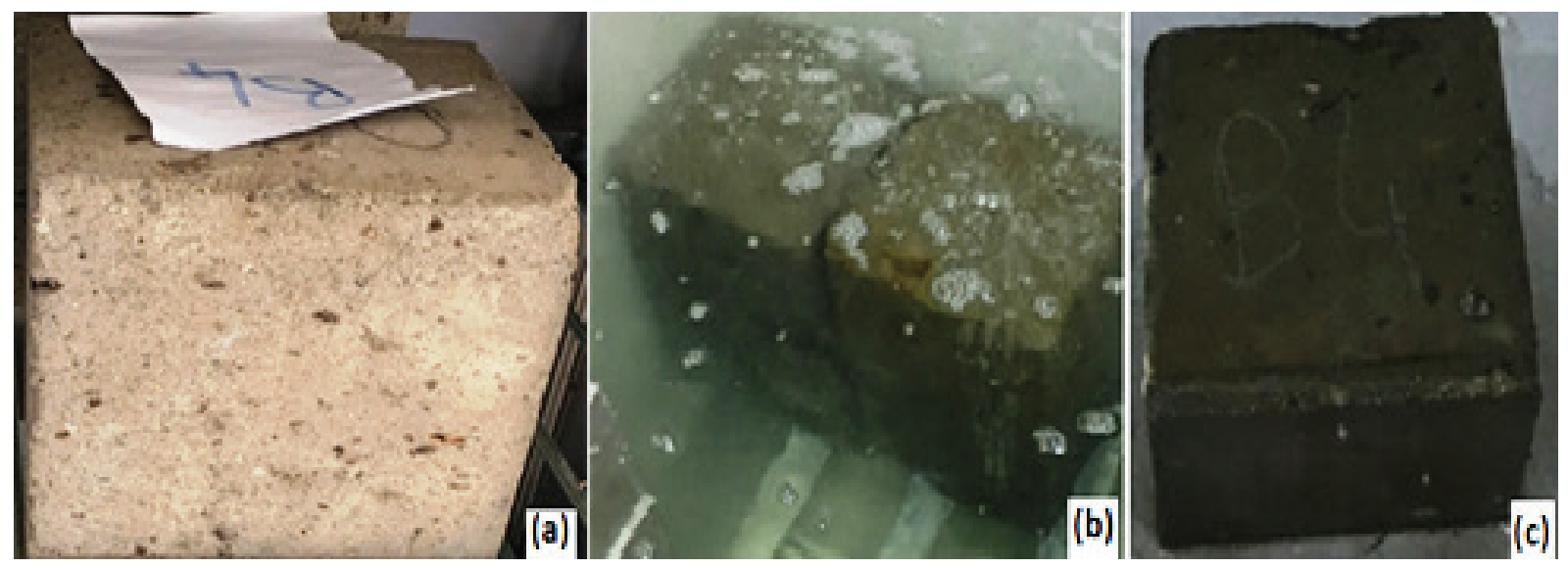

FIGURE 2. Images of samples prepared in dimensions of $15 \mathrm{~cm} \times 15 \mathrm{~cm} \times 15 \mathrm{~cm}$. 
determine the maximum heavy metal concentration that can leak from the waste or any material as a worst-case scenario (21). According to procedure at first the material was crushed and passed through a sieve with a mesh size $9.5 \mathrm{~mm}$. Then $100 \mathrm{~g}$ of the material was shaken in $2 \mathrm{~L}$ extraction liquid for 18 hours. At the end of the shaking period, the sample was filtered by means of a glass fiber filter with a pore size of $0.8 \mu \mathrm{m}(19,21)$. The filtrate's $\mathrm{pH}$ was determined as 4.86 .

The extraction fluid was filtered through a $0.45-\mu \mathrm{m}$ membrane filter and the trace metal concentrations in the leakage were measured by ICP MS according to the EPA 200.8 method (22).

\section{RESULTS AND DISCUSSION}

\subsection{Physical Properties}

While determining the physical and chemical properties of Bitlis stone, a sufficient amount of sample was used for each property. Firstly, the chemical composition values for Bitlis stone were obtained by the method (11) described by Koralay et al. (2014). In this study, three different levels of chemical analysis were used for Bitlis stone. The values obtained for three different levels were averaged (Table 1).

SEM experiments were performed to understand the morphology of the surfaces. Microstructural analysis of the sample was carried out by taking scanning electron microscope (SEM, ZEISS EVO MA10) images supported by energy-dispersive $\mathrm{X}$-ray spectrometer (EDX) spectra. Sample sizes were selected as $1 \times 1 \times 0.1 \mathrm{~cm}$. EDS measurements were performed to reveal the basic composition of Bitlis ignimbrites in the samples. The EDS results obtained for three different points are given in Figure 3. There were the elements of $\mathrm{O}, \mathrm{Si}, \mathrm{Fe}$, $\mathrm{Al}, \mathrm{K}$ and $\mathrm{Na}$ for three randomly selected points.

TABLE 1. Chemical properties of Bitlis stone (11)

\begin{tabular}{lc}
\hline Characteristic & Value \\
\hline $\mathrm{SiO}_{2}(\%)$ & 64.70 \\
$\mathrm{Al}_{2} \mathrm{O}_{3}(\%)$ & 13.06 \\
$\mathrm{Fe}_{2} \mathrm{O}_{3}(\%)$ & 4.55 \\
$\mathrm{CaO}(\%)$ & 2.40 \\
$\mathrm{MgO}(\%)$ & 0.45 \\
$\mathrm{P}_{2} \mathrm{O} 5(\%)$ & 0.24 \\
$\mathrm{~K} 2 \mathrm{O}(\%)$ & 4.62 \\
$\mathrm{Na} 2 \mathrm{O}(\%)$ & 5.11 \\
$\left.\mathrm{MnO}^{2} \%\right)$ & 0.12 \\
$\mathrm{TiO}_{2}$ & 0.40 \\
$\mathrm{Loss}$ on Ignition $(\%)$ & 3.24 \\
\hline
\end{tabular}

The percentage values of the elements were considered to differ from point to point. This shows that the material was not homogeneous. For example, the element $\mathrm{K}$ was located at the first and third points, but not at point 2. A high amount of Si was observed at all three points.

Unit volume weight (UVW) measurements were performed for the samples that were obtained. The mean unit volume weight values obtained from the samples are shown in Table 2. UVW values were quite small, and this was an indication that the stone was quite light and porous.

Samples prepared for determination of water absorption properties were kept in a water bath for 24 hours (Figure 2b). The weights of water absorption were then determined for samples extracted from the pool. The water absorption properties of Bitlis stone for 10 different samples are shown in Table 3.

The water absorption rate in natural building stones should not be less than 7.5\% (23). The water absorption rate of the Bitlis stone was significantly higher than this value. This shows that Bitlis stone has a very porous and hollow structure.

One of the important properties of Bitlis stone is good thermal insulation. For these purposes, the mean thermal conductivity coefficient $(\lambda)$ and specific heat values were obtained for all samples. The thermal properties obtained for the samples are given in Table 4. The coefficient of thermal conductivity is designed to be used in a laboratory. The coefficient of thermal conductivity values was obtained at our laboratory with a steady-state test apparatus designed and produced in the Mining Engineering Department of Dicle University.

The thermal conductivity coefficient for any material refers to the amount of heat transmitted by the physical and chemical properties of the material. Its low thermal conductivity value was a sign that Bitlis stone conveyed very little heat and it was determined that it is a material that may be used for thermal insulation.

Five different samples were used for measurements in the specific weight experiments (Table 5). Bitlis stone was dried and ground into a fine powder. The values required for specific weight were obtained with the pycnometer.

\subsection{Mechanical Properties}

In general, natural stones may be used as a loadbearing in structures. In this context, the pressure and tensile strength of these stones are important. The compressive strength values obtained from 10 different samples at two different institutions are given in Table 6.

Five different samples were used for testing the flexural strength of Bitlis stone. The obtained flexural strength results are given in Table 7. 

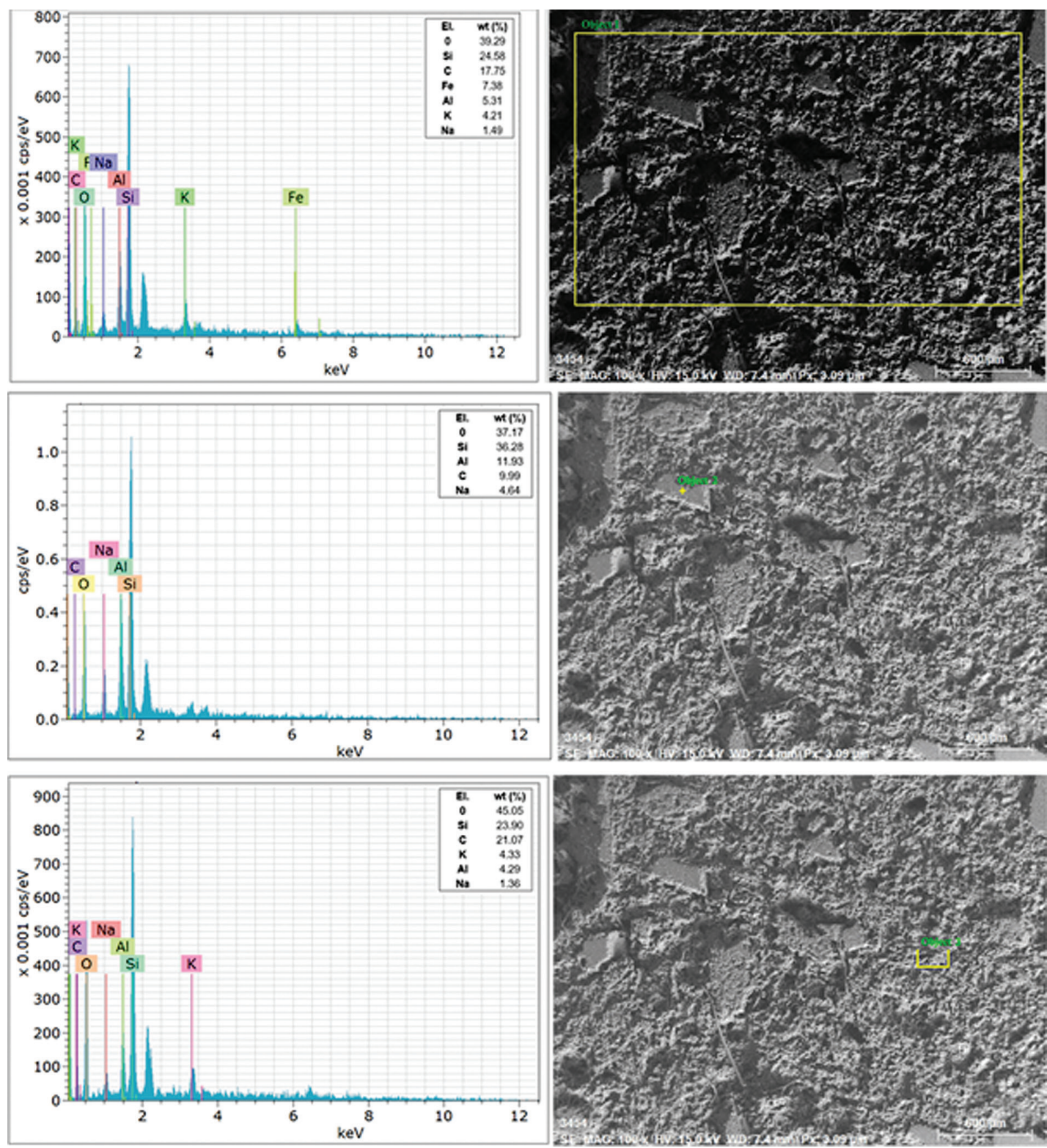

FIGURE 3. EDS results for 3 different points at room temperature.

Non-destructive testing (NDT) has an important place in determining the strength properties of natural stones and concretes that are used in construction. Destructive and non-destructive tests are widely used for testing the strength properties of natural stones and concretes. For example, Vasconcelos et al. (2007) (24) used non-destructive techniques for testing the elastic properties and strength of granitic rocks. Ultrasonic velocity $(\mathrm{Vp})$ and the Schmidt hammer were used to determine the strength characteristics of many different granites at two architectural heritage monuments $(25,26)$. Sharma et al. (2011) (26) established a statistical relationship between the
P-wave velocity and rebound numbers of the Schmidt hammer with the impact strength index. Karakuş and Tütmez (2006) (27) used uniaxial compressive strength, point loading index test, Schmidt hammer stiffness and ultrasonic pulse velocity (UPV) tests for nine different rocks. Sharma and Singh (2008) (28) determined the mechanical properties of three metamorphic, sedimentary and magmatic rocks depending on P-wave velocity. Kurtuluş et al. (2010) (29) analyzed the mechanical and physical properties of andesites in Gökçeada. Ahlat natural stones (ignimbrites) were studied for industrial use $(30,31)$. Pamuk and Büyüksaraç (2017) (32) used destructive 
and non-destructive methods to determine the mechanical properties of natural rocks in the vicinity of Urgup (Nevşehir).

The propagation changes of the UPV wave are analyzed and applied without creating a deformation in the material in the UPV method. This method, which enables investigation of material homogeneity, may be considered as an important method in evaluation of concrete or natural stone structures (33). In this method, based on the propagation speed of the ultrasonic sound waves at the specific frequencies in the sample, an idea of is obtained about the strength of the sample. Sound waves provide an idea of the cracks in the sample. Ultrasonic pulse is applied to one side of the sample by an ultrasonic tester and pressure waves ( $\mathrm{P}$ wave) are created and recorded from the other side of the sample. The ultrasonic tester

TABLE 2. Values of unit volume weight of Bitlis stone (sample size $15 \times 15 \times 15 \mathrm{~cm}$ )

\begin{tabular}{lcccc}
\hline $\begin{array}{l}\text { Sample } \\
\text { ID }\end{array}$ & $\begin{array}{c}\text { Wet } \\
\text { Weight } \\
\text { (gr) }\end{array}$ & $\begin{array}{c}\text { Dry } \\
\text { Weight } \\
(\mathbf{g r})\end{array}$ & $\begin{array}{c}\text { Dry Density } \\
(\mathbf{g r / c m})\end{array}$ & $\begin{array}{c}\text { Wet Density } \\
\left(\mathbf{g r} / \mathbf{c m}^{3}\right)\end{array}$ \\
\hline B1 & 6050 & 4981 & 1.48 & 1.79 \\
B2 & 5950 & 4896 & 1.45 & 1.76 \\
B3 & 5850 & 4760 & 1.41 & 1.73 \\
B4 & 6150 & 5051 & 1.50 & 1.82 \\
B5 & 6190 & 5093 & 1.51 & 1.83 \\
B6 & 5904 & 4854 & 1.44 & 1.75 \\
B7 & 5948 & 4893 & 1.45 & 1.76 \\
B8 & 6122 & 5042 & 1.49 & 1.81 \\
B9 & 5990 & 4893 & 1.45 & 1.77 \\
B10 & 5995 & 4920 & 1.46 & 1.78 \\
Average & & & $1.46 \pm 0.03$ & $1.78 \pm 0.03$ \\
\hline
\end{tabular}

measures the travel time between the surface of the ultrasonic wave and the surface from which the sample is returned. UPV equipment consists of a receiver, a transmitter and a display (26). Equation [1] presents determination of the impact speed. The propagation times of the waves read from the instrument's gauge were divided by the size of the sample as indicated in the equation and the propagation rates were determined for each sample.

UPV test was applied on 10 cube samples, before the $15 \mathrm{~cm} \times 15 \mathrm{~cm} \times 15 \mathrm{~cm}$ cube samples were prepared for destructive pressure tests (Figure 1). UPV

TABLE 4. Thermal conductivity and specific heat values of Bitlis stone

\begin{tabular}{llll}
\hline Sample ID & $\boldsymbol{\lambda}(\mathbf{W} / \mathbf{m} \cdot \mathbf{K})$ & $\left(\mathbf{J}^{\mathbf{3}}{ }^{\mathbf{C P}} \cdot \mathbf{K}\right) \mathbf{1 0}^{\mathbf{6}}$ & $\begin{array}{c}\text { Ambient } \\
\text { temperature }\left({ }^{\circ} \mathbf{C}\right)\end{array}$ \\
\hline 1 & 0.513 & - & 16 \\
2 & 0.463 & & 15.7 \\
3 & 0.46 & & 19.1 \\
4 & 0.513 & 1.37 & 19.4 \\
5 & 0.697 & & 18.75 \\
6 & 0.446 & & 21.3 \\
7 & 0.511 & & 21 \\
8 & 0.532 & 1.4 & 20.4 \\
9 & 0.611 & & 20.03 \\
10 & 0.487 & & 20.01 \\
11 & 0.556 & 1.55 & 20.3 \\
12 & 0.467 & & 20.36 \\
13 & 0.413 & & 20.4 \\
14 & 0.5 & 1.47 & 20.46 \\
15 & 0.888 & 1.39 & 20.47 \\
16 & 0.573 & & 20.13 \\
Average & $0.54 \pm 0.12$ & $1.44 \pm 0.07$ & $19.61 \pm 1.6$ \\
\hline
\end{tabular}

TABLE 3. Water absorption properties of Bitlis stone

\begin{tabular}{lcccccc}
\hline Sample ID & $\begin{array}{c}\text { Wet Weight } \\
\text { (gr) }\end{array}$ & $\begin{array}{c}\text { Dry Weight } \\
\text { (gr) }\end{array}$ & $\begin{array}{c}\text { Water Saturated } \\
\text { Weight (gr) }\end{array}$ & $\begin{array}{c}\text { Water Absorption } \\
\text { Weight (gr) }\end{array}$ & $\begin{array}{c}\text { Water Absorption } \\
\text { Percentage by Weight (Sa) }\end{array}$ & $\begin{array}{c}\text { Water Absorption } \\
\text { Percentage as Volume (Sh) }\end{array}$ \\
\hline B1 & 6050 & 4981 & 6100 & 1119 & 22.47 & 33.16 \\
B2 & 5950 & 4896 & 6000 & 1104 & 22.55 & 32.71 \\
B3 & 5850 & 4760 & 5950 & 1190 & 25.00 & 35.26 \\
B4 & 6150 & 5051 & 6200 & 1149 & 22.75 & 34.04 \\
B5 & 6190 & 5093 & 6250 & 1157 & 22.71 & 34.27 \\
B6 & 5904 & 4854 & 5980 & 1126 & 23.21 & 33.37 \\
B7 & 5948 & 4893 & 6070 & 1177 & 24.05 & 34.87 \\
B8 & 6122 & 5042 & 6215 & 1173 & 23.26 & 34.76 \\
B9 & 5990 & 4893 & 6080 & 1187 & 24.26 & 35.17 \\
B10 & 5995 & 4920 & 6085 & 1165 & 23.68 & 34.52 \\
Average & & & & & $23.39 \pm 0.84$ & $34.21 \pm 0.88$ \\
\hline
\end{tabular}


TABLE 5. Specific weight values

\begin{tabular}{lccc}
\hline Sample ID & $\mathbf{P}_{\text {sample }}$ & Full volume & Specific weight \\
\hline 1 & 50 & 24.00 & 2.08 \\
2 & 50 & 24.50 & 2.04 \\
3 & 50 & 26.00 & 1.92 \\
4 & 50 & 25.00 & 2.00 \\
5 & 50 & 25.50 & 1.96 \\
Average & & & $2 \pm 0.063$ \\
\hline
\end{tabular}

TABLE 6. Bitlis stone compressive strength values (sample size $15 \times 15 \times 15 \mathrm{~cm}$ )

\begin{tabular}{lcc}
\hline Sample ID & Breaking Load $(\mathbf{k N})$ & Pressure Strain $(\mathbf{M P a})$ \\
\hline B1 & 166.5 & 7.40 \\
B2 & 172.5 & 7.67 \\
B3 & 175.6 & 7.80 \\
B4 & 172.2 & 7.65 \\
B5 & 179.5 & 7.98 \\
B6 & 163.8 & 7.28 \\
B7 & 146.4 & 6.51 \\
B8 & 153.2 & 6.81 \\
B9 & 164.8 & 7.32 \\
B10 & 170.2 & 7.56 \\
Average & & $7.40 \pm 0.426$ \\
\hline
\end{tabular}

TABLE 7. Flexural strength values for Bitlis stone (sample size $15 \times 15 \times 15 \mathrm{~cm}$ )

\begin{tabular}{lcc}
\hline Sample ID & Breaking Load $(\mathbf{k N})$ & Tensile Strength (MPa) \\
\hline B1 & 23.1 & 1.03 \\
B2 & 26.2 & 1.16 \\
B3 & 26.5 & 1.18 \\
B4 & 24.2 & 1.08 \\
B5 & 25.5 & 1.13 \\
Average & & $1.116 \pm 0.054$ \\
\hline
\end{tabular}

measurements were performed using the direct transmission method with Pundit Plus and $1 \mathrm{MHz}$ probes. The measurements were made on cubic samples along the $\mathrm{x}, \mathrm{y}$ and $\mathrm{z}$ directions and three measurements were taken for each direction. $54 \mathrm{kHz}$ piezoelectric transceiver probes were used to determine the longitudinal wave velocities. The speed was calculated directly using Equation [1]. The average velocity values were calculated based on the number of measurements made for each direction. It can be seen that the variability of the UPV results depended on the measurement direction. Impact velocities are determined using a direct method used for opposite faces for samples. Table 8 reports the average speed
TABle 8. Ultrasonic Pulse Velocity tests (sample size $15 \times 15 \times 15 \mathrm{~cm}$ )

\begin{tabular}{lc}
\hline Sample ID & UPV $\left(\mathbf{k m} \cdot \mathbf{s}^{-\mathbf{1}}\right)$ \\
\hline B1 & 1.56 \\
B2 & 1.87 \\
B3 & 1.93 \\
B4 & 1.56 \\
B5 & 1.69 \\
B6 & 1.78 \\
B7 & 1.61 \\
B8 & 1.39 \\
B9 & 1.79 \\
B10 & 1.54 \\
Average & $1.67 \pm 0.169$ \\
\hline
\end{tabular}

values of $\mathrm{P}$-waves recorded in three directions for each sample.

$$
\mathrm{Vp}=\mathrm{L} / \mathrm{tp}
$$

Where;

Vp: Pwave velocity $(\mathrm{km} / \mathrm{s})$

L: Distance between the surface where the sound wave is sent and the surface where the wave is received $(\mathrm{km})$

Tp: P-Wave propagation duration (s)

UPV values with breaking load and pressure stress were compared and the polynomial relationships calculated between them are shown in Figure 4. All physical and mechanical properties are summarized in Table 9.

\subsection{Radioactivity Properties}

\subsubsection{Gamma-ray Measurement}

${ }^{226} \mathrm{Ra},{ }^{232} \mathrm{Th},{ }^{40} \mathrm{~K}$ and ${ }^{137} \mathrm{Cs}$ radionuclide activity concentrations were determined by using an n-type HP Ge detector with energy resolution of $2.1 \mathrm{keV}$ at $1.33 \mathrm{MeV}$ and a relative efficiency of $50 \%$. Detector energy and efficiency calibrations were performed by using a standard multi-nuclide source with $1.7 \mathrm{gcm}^{-3}$ of density and an activity of $1.365 \mathrm{mCi}\left({ }^{57} \mathrm{Co},{ }^{60} \mathrm{Co},{ }^{88} \mathrm{Y},{ }^{109} \mathrm{Cd},{ }^{139} \mathrm{Ce},{ }^{137} \mathrm{Cs},{ }^{203} \mathrm{Hg}\right.$, ${ }^{210} \mathrm{~Pb}$ and $\left.{ }^{241} \mathrm{Am}\right)$. Sample and background counts were performed in $86400 \mathrm{~s}$ (1 day) intervals and the spectra were analyzed on the Gamma Vision (ORTEC) software (34) for ${ }^{226} \mathrm{Ra},{ }^{232} \mathrm{Th},{ }^{40} \mathrm{~K}$ and ${ }^{37} \mathrm{Cs}$ radionuclides. For determination of specific activities, the daughter radionuclide gamma ray lines of 351.93 and $609.32 \mathrm{keV}\left({ }^{214} \mathrm{~Pb}\right.$ and $\left.{ }^{214} \mathrm{Bi}\right)$ for ${ }^{226} \mathrm{Ra}$ and $911.2 \mathrm{keV}\left({ }^{228} \mathrm{Ac}\right)$ for ${ }^{232} \mathrm{Th}$ were used. Characteristic gamma peaks at $1,460.8 \mathrm{keV}$ and 


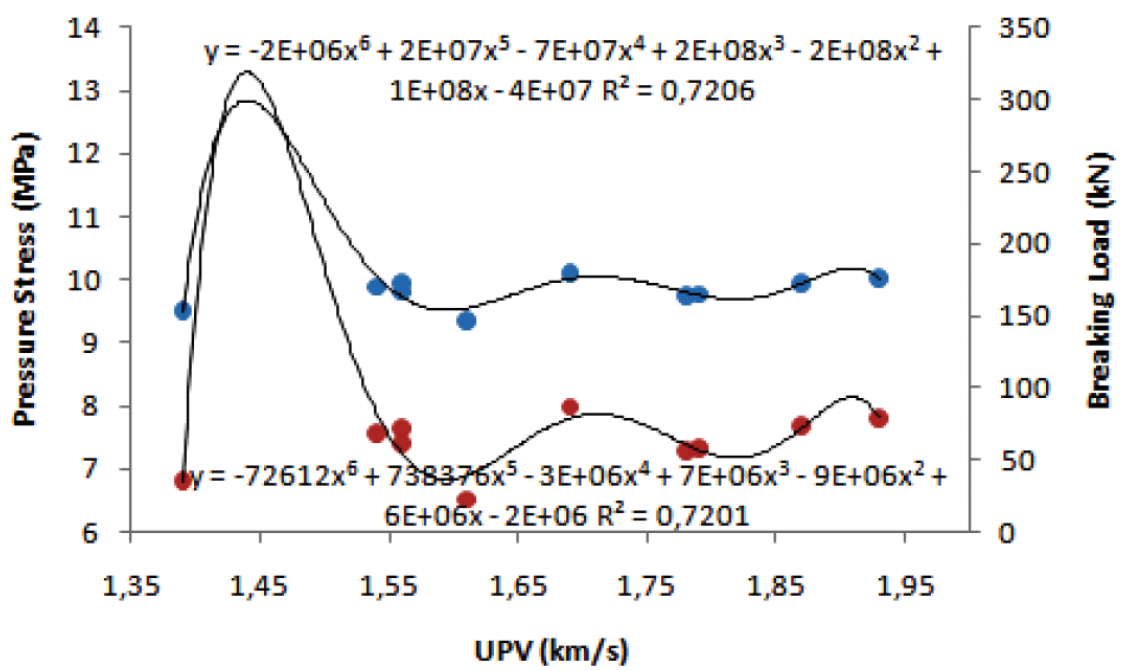

FIGURE 4. Comparing UPV, breaking load and pressure stress.

TABLE 9. Physical and mechanical characteristics of Bitlis stone for ten samples

\begin{tabular}{|c|c|c|c|c|c|c|c|c|c|c|}
\hline & B1 & B2 & B3 & B4 & B5 & B6 & B7 & B8 & B9 & B10 \\
\hline Dry Density $\left(\mathrm{gr.cm}^{-3}\right)$ & 1.48 & 1.45 & 1.41 & 1.50 & 1.51 & 1.44 & 1.45 & 1.49 & 1.45 & 1.46 \\
\hline Wet Density $\left(\mathrm{gr} \mathrm{cm}^{-3}\right)$ & 1.79 & 1.76 & 1.73 & 1.82 & 1.83 & 1.75 & 1.76 & 1.81 & 1.77 & 1.78 \\
\hline Water Absorption Percentage by Weight (Sa) & 22.47 & 22.55 & 25 & 22.75 & 22.71 & 23.21 & 24.05 & 23.26 & 24.26 & 23.68 \\
\hline Water Absorption Percentage as Volume (Sh) & 33.16 & 32.71 & 35.26 & 34.04 & 34.27 & 33.37 & 34.87 & 34.76 & 35.17 & 34.52 \\
\hline Breaking Load $(\mathrm{kN})$ & 166.5 & 172.5 & 175.6 & 172.2 & 179.5 & 163.8 & 146.4 & 153.2 & 164.8 & 170.2 \\
\hline Pressure Strain (MPa) & 7.4 & 7.67 & 7.8 & 7.65 & 7.98 & 7.28 & 6.51 & 6.81 & 7.32 & 7.56 \\
\hline Tensile Strength (MPa) & 1.03 & 1.16 & 1.18 & 1.08 & 1.13 & \multicolumn{5}{|c|}{ No Data } \\
\hline UPV $\left(\mathrm{km} \cdot \mathrm{s}^{-1}\right)$ & 1.56 & 1.87 & 1.93 & 1.56 & 1.69 & 1.78 & 1.61 & 1.39 & 1.79 & 1.54 \\
\hline
\end{tabular}

$661.66 \mathrm{keV}$ were used for determination of ${ }^{40} \mathrm{~K}$ and ${ }^{137} \mathrm{Cs}$, respectively (35).

The gamma-ray activity $(\mathrm{Bq} / \mathrm{kg})$ for each radionuclide may be calculated with Equation [2]:

$$
A=\frac{N_{S}-N_{\mathrm{B}}}{\varepsilon \times P_{\gamma} \times t} \times \frac{1}{m}
$$

where $A, N_{S}, N_{B}, \varepsilon, P \gamma, t$ and $m$ are the activity $(\mathrm{Bq} / \mathrm{kg})$, the counts of the sample, the background count, the absolute Photoelectric efficiency, the branching ratio, the counting live time (s) and the mass of the sample ( $\mathrm{kg}$ or L), respectively, for certain radionuclides in a gamma ray with the energy $E$ (34). The minimum detectable activity (MDA) of the system was calculated by Equation [3]:

$$
M D A=\frac{2.71+4.65 \sqrt{N_{B}}}{\varepsilon \times P_{\gamma} \times t}
$$

where $N_{B}, \varepsilon, P \gamma$ and $t$ are count of background, absolute efficiency, branching ratio, counting live time for certain radionuclides in a gamma ray with the energy $E$, respectively (35).

\subsubsection{Radon Concentration Measurement}

CR-39 passive detector of $1 \mathrm{~cm} \times 1 \mathrm{~cm}$ dimensions with a diffusion chamber was placed into a cylindrical sample beaker and stored for 40 days. Then, the chemical etching process of exposed CR-39 detector was carried out for 4.5 hours in a $6.25 \mathrm{M} \mathrm{NaOH}$ solution at $70^{\circ} \mathrm{C}$. Etched detectors were counted in the RadoSYS automated counting system and count results were taken from the system as track density (track. $\mathrm{mm}^{-2}$ ). Then, the sample activity was calculated from Equation [4]:

$$
C_{R n}\left(B q . m^{-3}\right)=1000 \times T D \times C F / t
$$


Where $C_{R n}$ is the radon activity concentration $\left(\mathrm{Bq} \cdot \mathrm{m}^{-3}\right), T D$ is the track density (track. $\left.\mathrm{mm}^{-2}\right), C F$ is the calibration factor for CR-39 detectors provided by the manufacturer $\left(44.47\right.$ h.kBq. $\left[\mathrm{m}^{3}\right.$.(track. $\left.\left.\mathrm{mm}^{-2}\right)\right]^{-1}$ ) and $t$ is the exposure time (h) (36).

\subsubsection{Photon Attenuation Coefficient Experiment}

The mass attenuation coefficient $(\mu / \rho)$ of Bitlis stone was determined by measuring the transmission of $\gamma$-rays with different energies through targets of different thicknesses of the sample (Figure 5) (16). The gamma activity concentrations of Bitlis stone are presented in Tables 10 and 11 . The gamma activity concentrations were higher than other building materials such as Ahlat stone, pumice and perlite, which are extracted from or produced in the same region.

The radon concentration of Bitlis stone was determined as $497.66 \mathrm{~Bq} . \mathrm{m}^{-3}$. This value was higher than the permitted indoor radon gas activity level that was determined as $400 \mathrm{~Bq} \cdot \mathrm{m}^{-3}$ for Turkey by the Turkish Atomic Energy Authority (37). Additionally, the radon concentration of Bitlis stone was lower in comparison to the radon levels in building materials such as Ahlat stone and pumice, which are extracted from or produced in the same region (Table 12).

The mass attenuation coefficients of Bitlis stone were determined for an 80-1332 keV energy range (Figure 6). The mass attenuation characteristics of
Bitlis stone were lower than some concrete types used in constructions (Table 13).

\subsection{Determination of Environmental Toxicity Leaching Characteristics}

At another stage of the study; the toxicity characteristics of Bitlis stone, which is specific to the Bitlis Region, extracted from quarries and used as a building material, were investigated. The material known as Bitlis ignimbrite includes significant amount of main oxides such as; $\mathrm{SiO}_{2}, \mathrm{Al}_{2} \mathrm{O}_{3}, \mathrm{~K}_{2} \mathrm{O}$, $\mathrm{Fe}_{2} \mathrm{O}_{3}, \mathrm{Na}_{2} \mathrm{O}$ (by respectively approx; $65 \%, 14 \%, 5 \%$, $4 \%, 4 \%)(11)$.

Trace metal analysis results obtained in the study are given in Table 14. When the results are compared to the TCLP limits, it is seen that the limit values for

TABle 10. Point sources, their energies and activities for linear attenuation experiment

\begin{tabular}{lcc}
\hline Radioisotope & Energy $(\mathbf{k e V})$ & Activity $(\boldsymbol{\mu C i})$ \\
\hline${ }^{133} \mathrm{Ba}$ & 80 & 0.71 \\
${ }^{133} \mathrm{Ba}$ & 356 & 0.71 \\
${ }^{22} \mathrm{Na}$ & 511 & 0.27 \\
${ }^{137} \mathrm{Cs}$ & 662 & 0.92 \\
${ }^{60} \mathrm{Co}$ & 1173 & 0.52 \\
${ }^{22} \mathrm{Na}$ & 1274 & 0.27 \\
${ }^{60} \mathrm{Co}$ & 1332 & 0.52
\end{tabular}

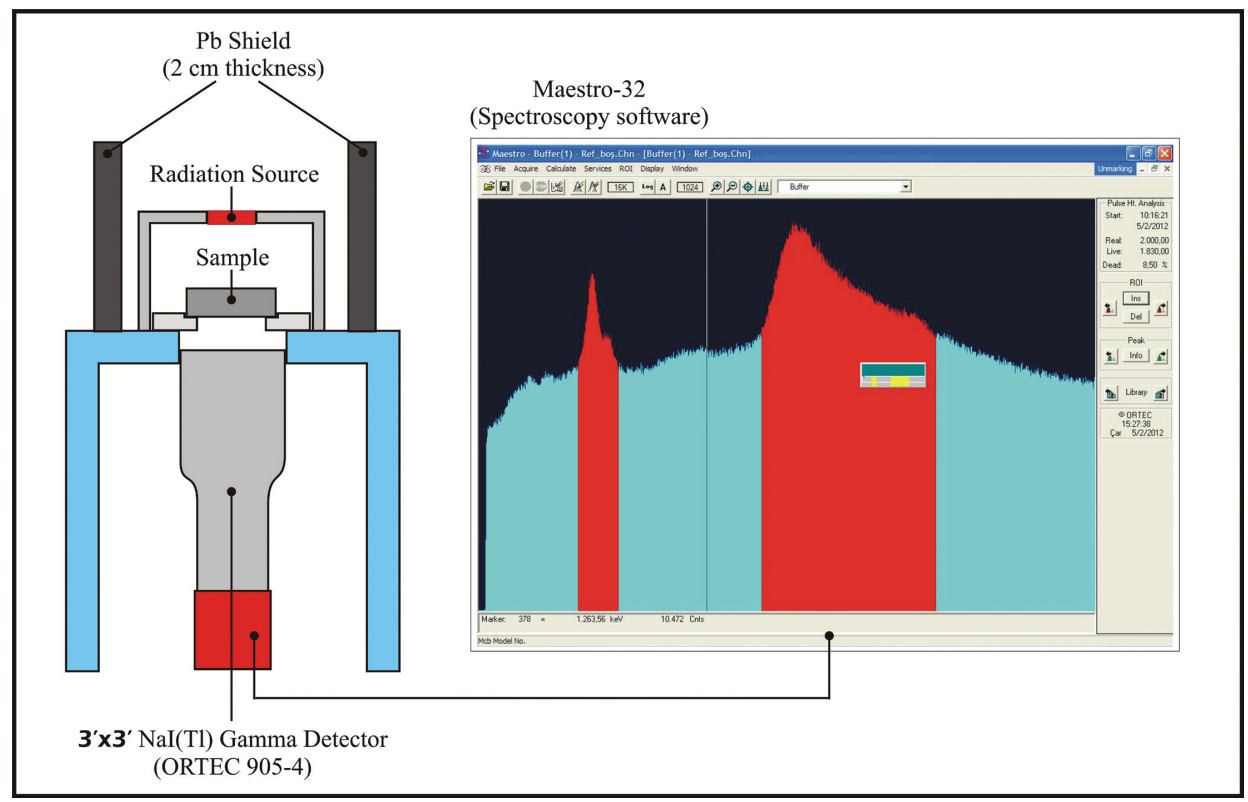

FIGURE 5. Experimental setup of mass attenuation coefficient determination. 
TABLE 11. Gamma activity concentrations of Bitlis stone

\begin{tabular}{|c|c|c|c|c|c|}
\hline \multirow[b]{2}{*}{ Radioisotope } & \multicolumn{4}{|c|}{ Gamma activities of Bitlis stone (Bq.kg $\left.{ }^{-1}\right)$} & \multirow[b]{2}{*}{ Reference } \\
\hline & ${ }^{226} \mathbf{R a}$ & ${ }^{232} \mathrm{Th}$ & ${ }^{40} \mathbf{K}$ & ${ }^{137} \mathrm{Cs}$ & \\
\hline Ahlat stone & $94.3 \pm 19.25$ & $23.7 \pm 14.15$ & $1026.6 \pm 263.1$ & & (14) \\
\hline Pumice & $180.8 \pm 77.5$ & $23.6 \pm 5.9$ & $249.3 \pm 124.7$ & & (14) \\
\hline Perlite & $228.2 \pm 38.1$ & $95.5 \pm 26.1$ & $642.4 \pm 275.3$ & & (14) \\
\hline Bitlis stone & $118.854 \pm 0.962$ & $141.376 \pm 1.964$ & $3,031.758 \pm 14.255$ & $<\mathrm{MDA}$ & Present Study \\
\hline MDA & 1.012 & 0.639 & 7.818 & 0.092 & \\
\hline
\end{tabular}

$\mathrm{Cd}$ and $\mathrm{Pb}$ heavy metals exceeded the TCLP limits. In this case, it is considered that this material can release these heavy metals to the environment in extreme environmental conditions (i.e. acid rain) which may pose a risk. In this context, the worstcase scenario is that the material was considered as waste material. In this case, metal leakage from Bitlis ignimbrite was examined in terms of waste landfilling criteria. In comparison to the USEPA Land Disposal Limits, the Cd (approximately 13 times) and $\mathrm{Pb}$ (75 times) amounts leached from the material exceeded the limit values. Considering the

TABLE 12. Radon concentrations of construction materials from the Bitlis Region

\begin{tabular}{lcl}
\hline Construction Material & $\begin{array}{c}\text { Radon Concentration } \\
\left(\mathbf{B q} \cdot \mathbf{m}^{-3}\right)\end{array}$ & Reference \\
\hline Ahlat stone (mean) & $641.4 \pm 124.97$ & $(14)$ \\
Pumice & $1102.8 \pm 234.5$ & $(14)$ \\
Perlite & $1141.0 \pm 255.0$ & $(14)$ \\
Bitlis stone & $497.66 \pm 8.54$ & Present Study \\
\hline
\end{tabular}

limitations specified in the Regulation on Land filling of Wastes (RLW) for Turkey, it was noted that the $\mathrm{Ni}$ (1.1 times), $\mathrm{Cu}$ (1.01 times), $\mathrm{Zn}$ (11.4 times), $\mathrm{Cd}$ (2.8 times), $\mathrm{Ba}$ (3.7 times) and $\mathrm{Pb}$ (11.2 times) trace metals were seen to exceed the limit values in terms of land filling hazardous wastes. These overall environmental results indicated that this volcanic material should be carefully investigated in terms of toxicity before being used as a construction material.

\section{CONCLUSIONS}

Bitlis natural stone is appropriate for isolation due to the optimal thermal permeability coefficient (quantity $>32 \%$ ). Its porosity indicates a good percentage of water absorption what is optimal for maintaining the humidity in the buildings. The value of the thermal permeability coefficient revealed the usability of this stone for insulation. The unit volume weight and specific gravity values were very low and may be evaluated within the scope of reduction of stone structure loads. Considering the compressive strength values obtained for Bitlis stone, it was observed that it corresponded to a low

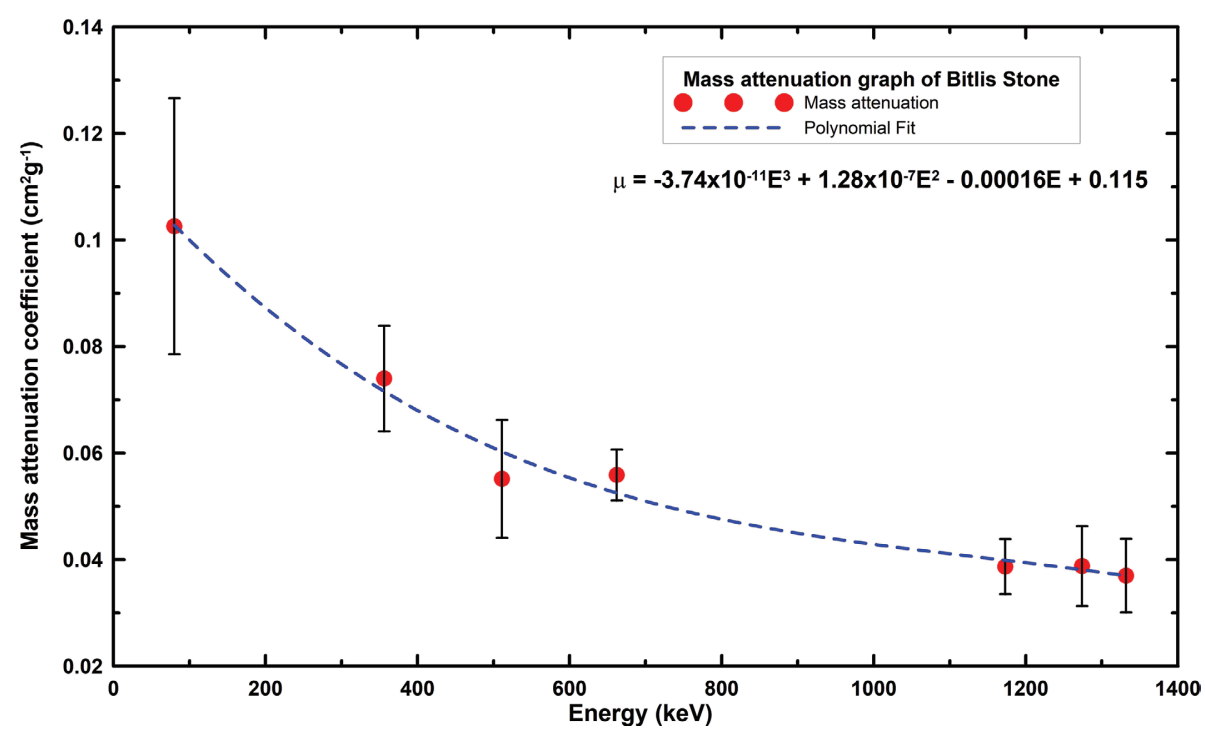

FIGURE 6. The mass attenuation coefficient of Bitlis stone. 
TABLE 13. The mass attenuation characteristics of stones in the region

\begin{tabular}{lccccl}
\hline Sample & Density $\left(\mathbf{g c} . \mathbf{m}^{\mathbf{- 3}}\right)$ & $\mathbf{6 6 2} \mathbf{~ k e V}$ & $\mathbf{1 1 7 3} \mathbf{~ k e V}$ & $\mathbf{1 3 3 2} \mathbf{~ k e V}$ & Reference \\
\hline BC0 & 2.46 & 0.257 & 0.174 & 0.165 & $(38)$ \\
BC50 & 2.99 & 0.287 & 0.175 & 0.167 & $(38)$ \\
BC100 & 3.46 & 0.297 & 0.180 & 0.170 & $(38)$ \\
Bitlis stone & 2.00 & 0.056 & 0.039 & 0.037 & Present Study \\
\hline
\end{tabular}

TABLE 14. Trace metal analysis results for crushed sample and TCLP extraction liquid in the context of the experimental study

\begin{tabular}{|c|c|c|c|c|c|c|c|c|c|}
\hline \multirow[b]{2}{*}{ Metals } & \multirow{2}{*}{$\begin{array}{c}\begin{array}{c}\text { Crushed } \\
\text { stone }\end{array} \\
\begin{array}{c}\text { Stone } \\
\text { (mg/kg) }\end{array}\end{array}$} & \multicolumn{3}{|c|}{$\begin{array}{l}\text { Amount leached } \\
\text { to TCLP liquid }\end{array}$} & \multirow{2}{*}{$\begin{array}{c}\text { TCLP } \\
\begin{array}{c}\text { Limit } \\
(\mathrm{mg} / \mathrm{L})\end{array} \\
\end{array}$} & \multirow{2}{*}{$\begin{array}{c}\text { EPA Land } \\
\text { Disposal } \\
\text { Restriction } \\
\text { Limits }(\mathbf{m g} / \mathrm{L}) \\
(21)(22)\end{array}$} & \multicolumn{3}{|c|}{ Turkish Regulation on Landfilling of Wastes (39) } \\
\hline & & $\begin{array}{c}\text { Stone } \\
(\mathrm{mg} / \mathrm{kg})\end{array}$ & $\begin{array}{c}\text { Leached } \\
(\%)\end{array}$ & $\begin{array}{c}\text { TCLP } \\
\text { liquid } \\
(\mathrm{mg} / \mathrm{L})\end{array}$ & & & $\begin{array}{c}\text { Landfilling } \\
\text { criteria for inert } \\
\text { wastes }(\mathrm{mg} / \mathrm{L})\end{array}$ & $\begin{array}{c}\text { Landfilling criteria } \\
\text { for non-hazardous } \\
\text { wastes }(\mathrm{mg} / \mathrm{L})\end{array}$ & $\begin{array}{c}\text { Landfilling criteria } \\
\text { for hazardous } \\
\text { wastes (mg/L) }\end{array}$ \\
\hline $\mathrm{Be}$ & 2.4 & 0.067 & 2.7 & 3.3 & - & - & - & - & - \\
\hline B & 256.7 & 36.4 & 14.2 & 1819 & - & - & - & - & - \\
\hline $\mathbf{N a}$ & 30213.9 & ND & ND & ND & - & - & - & - & - \\
\hline Al & 4337.8 & 5.5 & 0.1 & 276 & - & - & - & - & - \\
\hline $\mathbf{K}$ & 36986.1 & 352.4 & 1.0 & 17619 & - & - & - & - & - \\
\hline $\mathrm{Ca}$ & 2286.5 & 734.7 & 32.1 & 36735 & - & - & - & - & - \\
\hline V & 43.9 & 0.053 & 0.1 & 2.644 & - & - & - & - & - \\
\hline $\mathrm{Cr}$ & 4.9 & ND & ND & ND & 5 & 0.6 & 0.05 & 1 & 7 \\
\hline Mn & 400.7 & 19.6 & 4.9 & 980 & - & - & - & - & - \\
\hline $\mathrm{Fe}$ & 27196 & 1.2 & 0.0 & 62 & - & - & - & - & - \\
\hline Co & 0.846 & 0.021 & 2.5 & 1.1 & - & - & - & - & - \\
\hline $\mathbf{N i}$ & 3.3 & 0.086 & 2.6 & 4.3 & & 11 & 0.04 & 1 & 4 \\
\hline $\mathrm{Cu}$ & 4.4 & 0.202 & 4.5 & 10.1 & - & - & 0.2 & 5 & 10 \\
\hline $\mathbf{Z n}$ & 65.8 & 4.6 & 7.0 & 229 & & 4.3 & 0.4 & 5 & 20 \\
\hline As & 4.8 & ND & ND & ND & 5 & - & 0.05 & 0.2 & 2.5 \\
\hline Se & ND & ND & ND & ND & - & - & 0.01 & 0.05 & 0.7 \\
\hline $\mathrm{Sr}$ & 22.2 & 5.9 & 26.6 & 296 & - & - & - & - & - \\
\hline Cd & 0.146 & 0.028 & 19.4 & 1.41 & 1 & 0.11 & 0,004 & 0.1 & 0.5 \\
\hline $\mathbf{B a}$ & 495.6 & 2.2 & 0.5 & 112 & - & - & 2 & 10 & 30 \\
\hline $\mathbf{P b}$ & 9.5 & 1.1 & 11.8 & 56 & 5 & 0.75 & 0.05 & 1 & 5 \\
\hline $\mathbf{S i}$ & 31289.1 & 7.066 & 0.023 & 353 & - & - & - & - & - \\
\hline $\mathbf{T i}$ & 321.8 & 0.0086 & 0.003 & 0.430 & - & - & - & - & - \\
\hline Mo & 0.188 & ND & ND & ND & - & - & 0.05 & 1 & 3 \\
\hline Sn & 0.423 & 0.00634 & 1.5 & 0.317 & - & - & - & - & - \\
\hline Sb & 0.049 & 0.00012 & 0.2 & 0.006 & - & - & 0.006 & 0.07 & 0.5 \\
\hline W & 0.179 & ND & ND & ND & - & - & - & - & - \\
\hline $\mathbf{H g}$ & 0.004 & ND & ND & ND & 0.2 & - & 0.001 & 0.02 & 0.2 \\
\hline $\mathbf{B i}$ & 0.004 & ND & ND & ND & - & - & - & - & - \\
\hline
\end{tabular}

ND: Not detected.

resistance rock group. According to the porosity values, Bitlis stone was located in the group with a lot of gaps. Since Bitlis stone is a light material according to concrete, it will be able to reduce the load values in buildings under earthquake effects.
The high extractability of toxic metals $(\mathrm{Pb}$ and $\mathrm{Cd})$ indicates that in the last step of the useful life of our studied material it could be produced environmental contamination of the land where the wastes are deposited. The ACI of Bitlis stone is higher 
than 1.0 , although the radon concentration is lower than other similar volcanic rocks which means there are some difficulties to use it directly indoor applications.

When the toxicity potential of Bitlis ignimbrite obtained from volcanic terrain was examined, it was seen that the limit values of TCLP were exceeded for the $\mathrm{Pb}$ and $\mathrm{Cd}$ heavy metals. Moreover, the $\mathrm{Ni}, \mathrm{Cu}$, $\mathrm{Zn}, \mathrm{Cd}, \mathrm{Ba}$ and $\mathrm{Pb}$ concentrations exceeded the limit values given for the land filling of hazardous waste in Turkey. This indicated that detailed toxicological investigations should be conducted before the material is used as a construction material. The results also demonstrate that environmental research is important in terms of volcanic materials which are used as construction purposes and should be conducted before the marketing step. When the UPV results were obtained, P-wave velocities ranged from $1.39 \mathrm{~km} . \mathrm{s}^{-1}$ to $1.93 \mathrm{~km} . \mathrm{s}^{-1}$.

According to radiological characteristics of Bitlis stone; ${ }^{226} \mathrm{Ra},{ }^{232} \mathrm{Th},{ }^{40} \mathrm{~K}$ and ${ }^{137} \mathrm{Cs}$ gamma radioisotope concentrations were relatively higher than Ahlat stone, pumice and perlite in the same region. On the contrary radon gas emission of Bitlis stone was relatively lower than that of Ahlat Stone, pumice and perlite. The mass attenuation characteristics of Bitlis stone were lower than some concrete types like $\mathrm{BC} 0, \mathrm{BC} 50$ and $\mathrm{BC} 100$ that are used in construction.

\section{ACKNOWLEDGEMENTS}

Authors would like to thank Mr. Kemal AY for reading and critiquing the manuscript. Authors extend their thanks to the anonymous reviewers for their constructive critiques.

\section{REFERENCES}

1. Van Zalinge, M.E.; Cashman, K.V.; Sparks, R.S.J. (2018) Causes of fragmented crystals in ignimbrites: a case study of the Cardones ignimbrite, Northern Chile. Bull Volcanol. 80 [3], 22. https://doi.org/10.1007/s00445-018-1196-2.

2. Şimşek, O.; Erdal, M. (2004) Ahlat Taşının (ignimbrit) bazı mekanik ve fiziksel özelliklerinin araştırılması. G. U. J. Sci. 17 [4], 71-78.

3. Jordan, N. J.; Rotolo, S.G.; Williams, R.; Speranza, F.; McIntosh, W.C.; Branney, M. J.; Scaillet, S. (2018) Explosive eruptive history of Pantelleria, Italy: Repeated caldera collapse and ignimbrite emplacement at a peralkaline volcano. J Volcano. Geoth. Res. 349, 47-73. https://doi. org/10.1016/j.jvolgeores.2017.09.013.

4. Liszewska, K. M.; White, J. C.; Macdonald, R.; Bagiński, B. (2018) Compositional and thermodynamic variability in a stratified magma chamber: Evidence from the Green Tuff Ignimbrite (Pantelleria, Italy). J. Petrol. 59 [12], 2245-2272. https://doi.org/10.1093/petrology/egy095.

5. Avery, M.S.; Gee, J.S.; Bowles, J.A.; Jackson, M. J. (2018) Paleointensity estimates from ignimbrites: The Bishop Tuff Revisited. Geochem. Geophy. Geosy. 19 [10], 3811-3831. https://doi.org/10.1029/2018GC007665.

6. Yüksek, S. (2019) Mechanical properties of some building stones from volcanic deposits of mount Erciyes (Turkey). Mater. Construc. 69 [334], e187. https://doi.org/10.3989/ mc.2019.04618.
7. Koralay, T.; Özkul, M.; Kumsar, H.; Celik, S. B.; Pektaş, K. (2011) The effect of welding degree on geotechnical properties of an ignimbrite flow unit: The Bitlis castle case (eastern Turkey). Environ. Earth. Sci. 64 [3], 869-881. https://doi.org/10.1007/s12665-011-0931-1.

8. Barbero-Barrera, M. M.; Flores-Medina, N.; MorenoFernández, E. (2019) Thermal, physical and mechanical characterization of volcanic tuff masonries for the restoration of historic buildings. Mater. Construcc. 69 [333], e179. https://doi.org/10.3989/mc.2019.12917.

9. Burgos, D.; Guzmán, A.; Hossain, K.M.A.; Delvasto, S. (2017) The use of a volcanic material as filler in self-compacting concrete production for lower strength applications. Mater. Construcc. 67 [325], e111. https://doi.org/10.3989/ mc.2017.09315

10. Wang, X.; Shen, X.; Wang, H.; Gao, C.; Zhang, T. (2016) Nuclear magnetic resonance analysis of freeze-thaw damage in natural pumice concrete. Mater. Construcc. 66 [322], e087. https://doi.org/10.3989/mc.2016.09014.

11. Koralay T.; Özkul M.; Kumsar H.; Celik S.B.; Pektaș, K. (2014) The Importance of Mineralogical, Petrographic and Geotechnical Studies in Historical Heritage: The Bitlis Castle Case (Bitlis-Eastern Anatolia). Selcuk University $J$. Engineer. Sci. Technol. 2 [3], 54-68. https://doi.org/10.15317/ Scitech.201439631.

12. Ivanović, M.D.; Kljajević, L.M.; Nenadović, M.; Bundaleski, N.; Vukanac, I.; Todorović, B.Ž.; Nenadović, S.S. (2018) Physicochemical and radiological characterization of kaolin and its polymerization products. Mater. Construcc. 68 [330], e155. https://doi.org/10.3989/mc.2018.00517.

13. Merdanoglu, B.; Altınsoy, N. (2006) Radioactivity concentrations and dose assessment for soil samples from Kestanbol granite area, Turkey. Radiat. Prot. Dosim. 121 [4], 399-405. https://doi.org/10.1093/rpd/ncl055.

14. Kayakökü, H.; Karatepe, Ş.; Dogru, M. (2016) Measurements of radioactivity and dose assessments in some building materials in Bitlis, Turkey. Appl. Radiat. Isotopes. 115, 172-179. https://doi.org/10.1016/j.apradiso. 2016.06.020.

15. ISRM (2007) The complete ISRM suggested methods for rock characterization, testing and monitoring: 1974-2006. In: Ulusay, R., Hudson, J.A. (Eds.), Suggested Methods Prepared by the ISRM Commission on Testing Methods, Compilation Arranged by the ISRM Turkish National Group. Kozan Ofset, Ankara, 628 pp.

16. Erdem, M.; Baykara, O.; Dogru, M.; Kuluöztürk, F. (2010) A novel shielding material prepared from solid waste containing lead for gamma ray. Radiat. Phys. Chem. 79 [9], 917-922. https://doi.org/10.1016/j.radphyschem. 2010.04.009.

17. Baykara, O.; Karatepe, Ş.; Doğru, M. (2011) Assessments of natural radioactivity and radiological hazards in construction materials used in Elazig, Turkey. Radiat. Measur. 46 [1], 153-158. https://doi.org/10.1016/j.radmeas.2010. 08.010 .

18. Trevisi, R.; Leonardi, F.; Risica, S.; Nuccetelli, C. (2018), Updated database on natural radioactivity in building materials in Europe. J. Environ. Radioactiv. 187, 90-105. https://doi.org/10.1016/j.jenvrad.2018.01.024.

19. EPA, 1992. Test Method 1311 - TCLP, Toxicity Characteristic Leaching Procedure.

20. https://www.bureauveritas.com/services+sheet/metalsminerals/toxicity-characteristic-leaching-procedure-tclp, Access on: 26.03.2019.

21. Bayraktar C.A.; Avşar E.; Toröz İ.; Alp K.; Hanedar A. (2015) Stabilization and solidification of electric arc furnace dust originating from steel industry by using low grade $\mathrm{MgO}$. Arch. Environ. Prot. 41 [4], 62-66. https://doi. org/10.1515/aep-2015-0040.

22. EPA, (1994) Determination of Trace Elements in Waters and Wastes by Inductively Coupled Plasma-Mass Spectrometry, https://www.epa.gov/sites/production/ files/2015-08/documents/method_200-8_rev_5-4_1994.pdf, Access on 26.03.2019.

23. TSE, 1987. Doğal yapı taşlarının muayene ve deney metotları (in Turkish), Türk Standartları Enstitüsü, Ankara. 
24. Vasconcelos, G.; Lourenço, P. B.; Alves, C. A.; Pamplona, J. (2007) Prediction of the mechanical properties of granites by ultrasonic pulse velocity and Schmidt hammer hardness. North American Masonry Conference June 3-7 Missouri USA.

25. Fort, R.; de Buergo, M. A.; Perez-Monserrat, E. M. (2013) Non-destructive testing for the assessment of granite decay in heritage structures compared to quarry stone. Int . J. Rock. Mech. Min. 61, 296-305. https://doi.org/10.1016/j. ijrmms.2012.12.048.

26. Sharma, P. K.; Khandelwal, M.; Singh, T. N. (2011) A correlation between Schmidt hammer rebound numbers with impact strength index, slake durability index and P-wave velocity. Int. J. Earth Sci. 100 [1], 189-195. https://doi. org/10.1007/s00531-009-0506-5.

27. Karakus, M.; Tütmez, B. (2006) Fuzzy and multiple regression modelling for evaluation of intact rock strength based on point load, Schmidt hammer and sonic velocity. Rock Mech. Rock Eng. 39 [1], 45-57. https://doi.org/10.1007/ s00603-005-0050-y.

28. Sharma, P. K.; Singh, T. N. (2008) A correlation between $\mathrm{P}$-wave velocity, impact strength index, slake durability index and uniaxial compressive strength. B. Eng. Geol. Environ. 67 [1], 17-22. https://doi.org/10.1007/s10064-007-0109-y.

29. Kurtuluş, C.; Irmak, T. S.; Sertçelik, I. (2010) Physical and mechanical properties of Gokceada: Imbros (NE Aegean Sea) island andesites. B. Eng. Geol. Environ. 69 [2], 321-324. https://doi.org/10.1007/s10064-010-0270-6.

30. Ișık, E.; Bakış, A.; Akıllı, A.; Hattaoğlu, F. (2015) Usability of Ahlat Stone as Aggregate in Reactive Powder Concrete. Int. J. App. Sci. Eng. Res. 4 [4], 507-514.
31. Dinçer, İ.; Özvan, A.; Akın, M.; Tapan, M.; Oyan, V. 2012) İnimbiritlerin kapiler su emme potansivellerinin değerlendirilmesi: Ahlat Tașı örneği. YYUFBED. 17 [2], 64-71. https://dergipark.org.tr/tr/pub/yyufbed/issue/21967/235855.

32. Pamuk, E.; Büyüksaraç, A. (2017) Investigation of strength characteristics of natural stones in Urgüp (Nevsehir/ Turkey). BUSciTech. 7 [2], 74-79. https://doi.org/10.17678/ beuscitech. 305653 .

33. Lorenzi, A.; Tisbierek, F.T; Silva, L. C. P (2007) Ultrasonic pulse velocity análysis in concrete specimens. In IV Conferencia Panamericana de END, Buenos Aires.

34. Karakaya, M. C. Dogru, M.; Karakaya, N.; Vural, H. C. Kuluöztürk, F.; Bal, S. Ș. (2015) Radioactivity concentrations and dose assessments of therapeutic peloids from some Turkish spas. Clay Miner. 50 [2], 221-232. https://doi. org/10.1180/claymin.2015.050.2.06.

35. Karakaya, M. C.;; Dogru, M.; Karakaya, N.; Kuluöztürk, F.; Nalbantçılar, M. T. (2017) Radioactivity and hydrochemical properties of certain thermal Turkish spa waters. J, Water Health. 15 [4], 591-601. https://doi.org/10.2166/wh.2017.263.

36. Rado SYS (2011) Radosys User Manuel, Hungary.

37. Turkish Atomic Energy Authority (TAEK) (2000) Unofficial Translation, (May), 1-5. https://www.oecd-nea. org/law/legislation/turkey.pdf

38. Akkurt, I.; Akyıldırım, H.; Mavi, B.; Kilincarslan, S.; Basyigit, C. (2010) Photon attenuation coefficients of concrete includes barite in different rate. Ann. Nucl. Energy. 37 [7], 910-914. https://doi.org/10.1016/j.anucene.2010.04.001.

39. RLW, (2010) Regulation on Landfilling of Wastes, Turkish Ministry of Environment and Forestry. Official gazette date and number: 26.03.2010; 27533. 